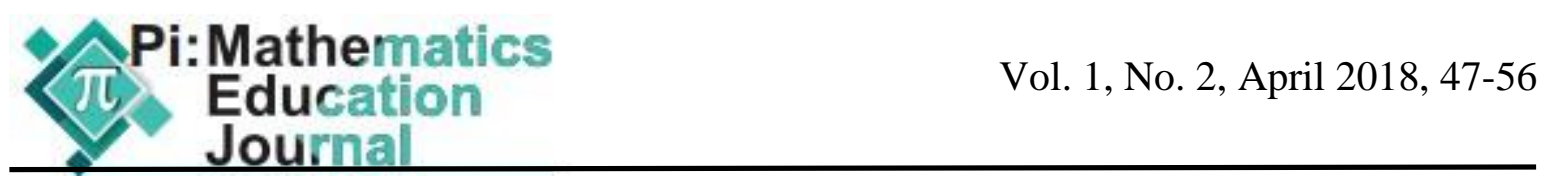

\title{
PELAKSANAAN LESSON STUDY FOR LEARNING COMMUNITY DI MGMP MATEMATIKA SMP KOTA MALANG TAHUN 2017
}

\author{
Lely Setyaningsih \\ SMP Negeri 7 Malang \\ lelynathan77@gmail.com
}

\begin{abstract}
Abstrak: Guru matematika harus selalu belajar demi meningkatkan kompetensi pedagogik dan kompetensi profesionalnya untuk menjadi fasilitator yang baik bagi peserta didik dalam menciptakan pembelajaran yang berkualitas dan menyenangkan. Lesson study merupakan salah satu model pembinaan terhadap guru melalui pengkajian kegiatan pembelajaran yang dilaksanakan secara kolaboratif dan berkelanjutan dalam membangun komunitas belajar. Lima belas guru matematika yang tergabung dalam MGMP Matematika SMP Kota Malang melaksanakan Lesson Study for Learning Community dalam 3 kegiatan plan dan 3 kegiatan dosee. Lesson study mampu meningkatkan kompetensi guru dan keaktifan peserta didik dalam pembelajaran.

Kata Kunci: Lesson Study for Learning Community, MGMP guru matematika SMP, kompetensi pedagogik, kompetensi profesional, peningkatan kompetensi.
\end{abstract}

\section{PENDAHULUAN}

Guru sebagai profesi kependidikan berdasarkan Permendiknas No 16 Tahun 2007 harus menguasai empat kompetensi yaitu kompetensi pedagogik, kompetensi kepribadian, kompetensi sosial dan kompetensi profesional dalam rangka meningkatkan kualitas peserta didik dalam pembelajaran. Didasari tuntutan empat kompetensi tersebut, maka seorang guru harus selalu belajar dan belajar agar mampu menjadi guru yang berkualitas. Salah satu bentuk kegiatan untuk meningkatan kompetensi pedagogik dan kompetensi profesional, guru-guru matematika SMP di kota Malang mengikuti program Lesson Study for Learning Community yang dibimbing oleh ahli lesson study dari Jepang bernama Mr.Ryo Suzuki, dosen Universitas Negeri Malang Bapak Saiful Hamzah dan pendamping bernama Aditya Syarif.

Menurut Grafield (2006) dalam Depdiknas (2009:1) lesson study berasal dari Jepang (jugyokenkyu) yaitu suatu proses sistematik yang digunakan oleh guru-guru Jepang untuk menguji keefektifan pengajarannya dalam rangka meningkatkan hasil pembelajaran. Sedangkan Friedkin (2005) mendefini- sikan lesson study sebagai proses yang melibatkan guru-guru yang bekerja sama dalam merencanakan, mengobservasi, menganalisis, dan memperbaiki pembelajaannya. Pembelajaran dalam lesson study sering juga disebut sebagai 'research lesson' atau pembelajaran penelitian.

Seiring dengan perkembangan dalam dunia pendidikan, guru masa kini diharapkan mampu menjadi fasilitator bagi peserta didik. Guru harus mampu membuat peserta didik selalu ingin tahu segala hal dalam ilmu pengetahuan yang luas di dunia ini dan mampu membuat peserta didik dapat belajar secara mandiri dan bekerjasama dalam komunitas belajarnya. Dengan kata lain, peserta didik tidak bergantung $100 \%$ pada guru dalam proses belajar. Karena guru hanya sebatas sebagai fasilitator sesuai dengan peran guru dalam lesson study.

Menurut Baba (2007), lesson study merujuk pada proses yang dilakukan guru yang secara progresif berusaha untuk meningkatkan metode pembelajaran mereka dengan cara bekerjasama dengan guru-guru lainnya. Sedangkan pendapat Sukirman (2006) memandang lesson study sebagai model pembinaan profesi pendidik melalui 
pengkajian pembelajaran secara kolaboratif dan berkelanjutan berkelanjutan berdasarkan prinsip-prinsip kolegalitas dan mutual learning untuk membangun learning community. Dengan demikian lesson study bukan suatu metode pembelajaran atau strategi pembelajaran. Namun demikian dalam suatu kegiatan lesson study dapat digunakan berbagai metode, strategi, atau pendekatan pembelajaran yang sesuai dengan situasi, kondisi, dan permasalahan yang dihadapi pendidik.

Tahapan dalam proses lesson study yang dikemukakan oleh Stigler dan Hiebert (Baba, 2007) ada tiga tahapan utama yaitu tahapan persiapan (plan), tahapan pelaksanaan pembelajaran (do), dan tahapan evaluasi (see). Pada tahapan persiapan terdiri atas 3 kegiatan yaitu identifikasi masalah, perencanaan kelas, dan mempersiapkan kelas. Pada tahapan evaluasi, setiap anggota tim secara bersama-sama memberikan refleksi terhadap tahapan pelaksanaan dan menemukan solusi untuk masalah yang muncul agar pembelajaran berikutnya dapat dipersiapkan dan dilaksanakan dengan baik. Perlu dipahami bahwa kegiatan refleksi bukan dimaksudkan untuk menilai kemampuan mengajar guru model, melainkan dimaksudkan untuk mencari temuan dan solusi terhadap masalah dalam pelaksanaan tahapan pembelajaran.

\section{DESKRIPSI KEGIATAN}

Kegiatan lesson study yang dilaksanakan di MGMP Matematika SMP Kota Malang menggunakan satu siklus. Ada 6 kegiatan pada hari yang berbeda meliputi 3 kegiatan perencanaan (plan) dan ada 3 kegiatan pelaksanaan-evaluasi (do-see). Ada 3 materi pembelajaran yang berhasil disusun dan dilaksanakan di tempat yang berbeda. Enam kegiatan tersebut di deskripsikan dalam enam pertemuan di tabel berikut:

Tabel 1. Enam Kegiatan Lesson Study For Learning Community

\begin{tabular}{|c|c|c|c|c|c|c|c|}
\hline 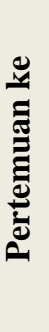 & 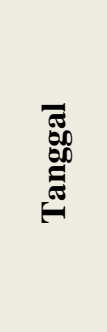 & & 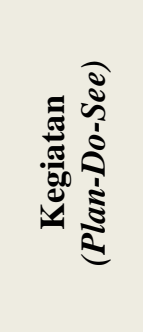 & 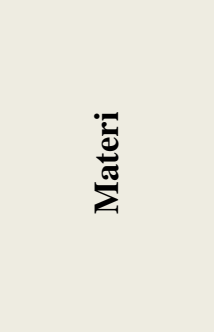 & 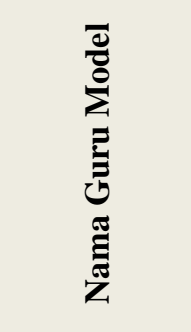 & 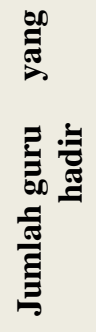 & 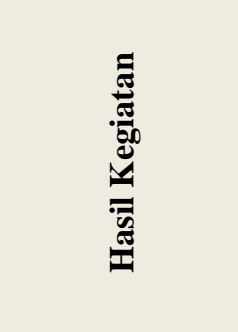 \\
\hline 1 & $\begin{array}{c}16 \\
\text { Maret } \\
2017\end{array}$ & $\begin{array}{c}\text { SMP } \\
\text { Negeri } 3 \\
\text { Malang }\end{array}$ & plan 1 & segi empat & Winda R. & 15 & $\begin{array}{c}\text { chapter design } \\
\text { dan } \\
\text { lesson design }\end{array}$ \\
\hline 2 & $\begin{array}{c}22 \\
\text { Maret } \\
2017\end{array}$ & $\begin{array}{c}\text { SMP } \\
\text { Barawijaya } \\
\text { Smart } \\
\text { School } \\
\text { Malang }\end{array}$ & do-see 1 & $\begin{array}{c}\text { segi empat } \\
\text { (menemukan } \\
\text { luas } \\
\text { jajargenjang } \\
\text { dan } \\
\text { trapesium) }\end{array}$ & Winda R. & 15 & $\begin{array}{c}\text { kemampuan } \\
\text { guru meningkat, } \\
\text { keaktifan siswa } \\
\text { meningkat, } \\
\text { siswa sasaran } \\
\text { menjadi aktif }\end{array}$ \\
\hline 3 & $\begin{array}{c}30 \\
\text { Maret } \\
2017 \\
\end{array}$ & $\begin{array}{c}\text { SMP } \\
\text { Negeri } 3 \\
\text { Malang } \\
\end{array}$ & plan 2 & $\begin{array}{l}\text { bangun ruang } \\
\text { sisi datar }\end{array}$ & Dwi Lestari & 15 & $\begin{array}{c}\text { chapter design } \\
\text { dan } \\
\text { lesson design }\end{array}$ \\
\hline 4 & $\begin{array}{c}4 \\
\text { April } \\
2017\end{array}$ & $\begin{array}{c}\text { SMP } \\
\text { Negeri } 9 \\
\text { Malang }\end{array}$ & do-see 2 & $\begin{array}{l}\text { bangun ruang } \\
\text { sisi datar } \\
\text { (menemukan } \\
\text { luas } \\
\text { permukaan }\end{array}$ & Dwi Lestari & 13 & $\begin{array}{l}\text { keaktifan siswa } \\
\text { meningkat, } \\
\text { siswa sasaran } \\
\text { tidak sesuai }\end{array}$ \\
\hline
\end{tabular}




\begin{tabular}{cccccc}
\hline Pi: Mathematics \\
Education \\
Journal
\end{tabular}

\section{Kegiatan Plan-Do-See 1}

Materi yang dipilih pada kegiatan ini yaitu materi segiempat tentang menemukan luas jajargenjang dan trapesium. Ketercapaian kegiatan pelaksanaan pembelajaran adalah $80 \%$ dari kegiatan perencanaan. Pada kegiatan perencanaan (plan), sebanyak 15 guru secara bersama-sama membuat chapter design dan lesson design yang ditampilkan pada gambar berikut:

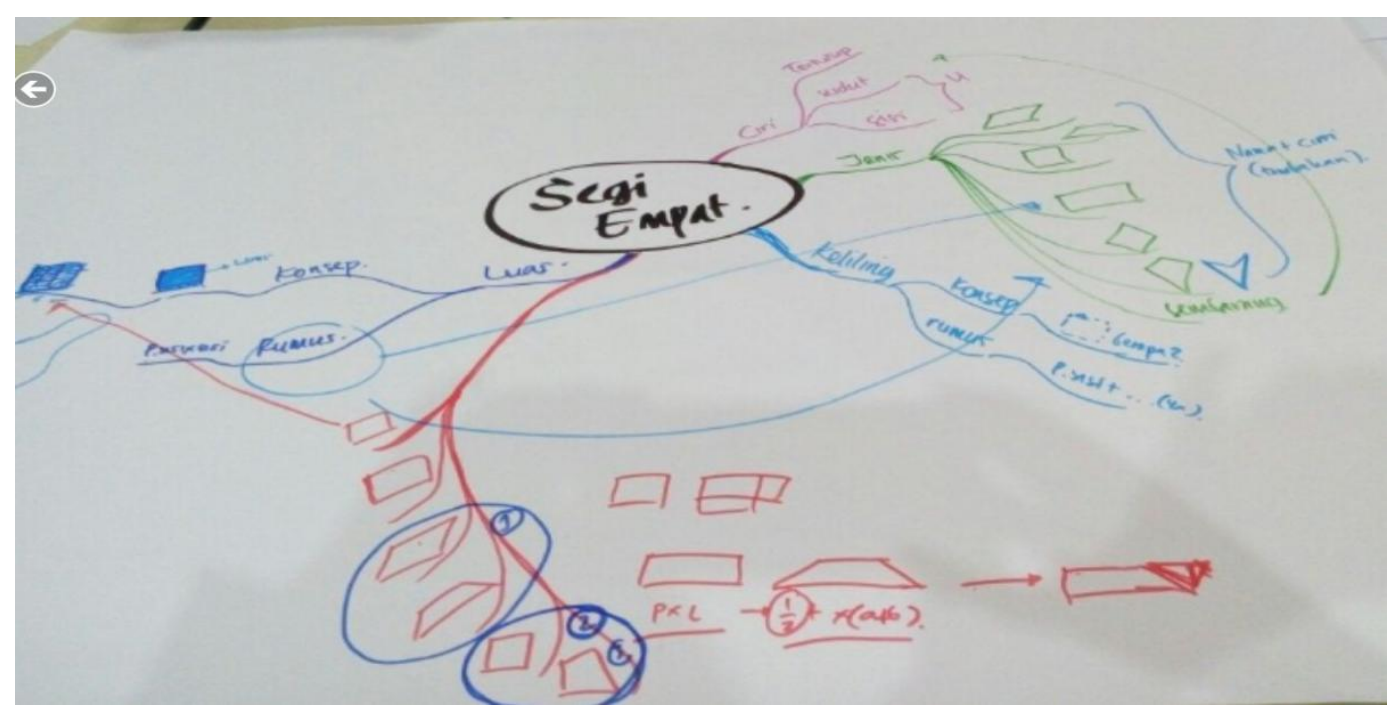

Gambar 1. Chapter Design plan 1 


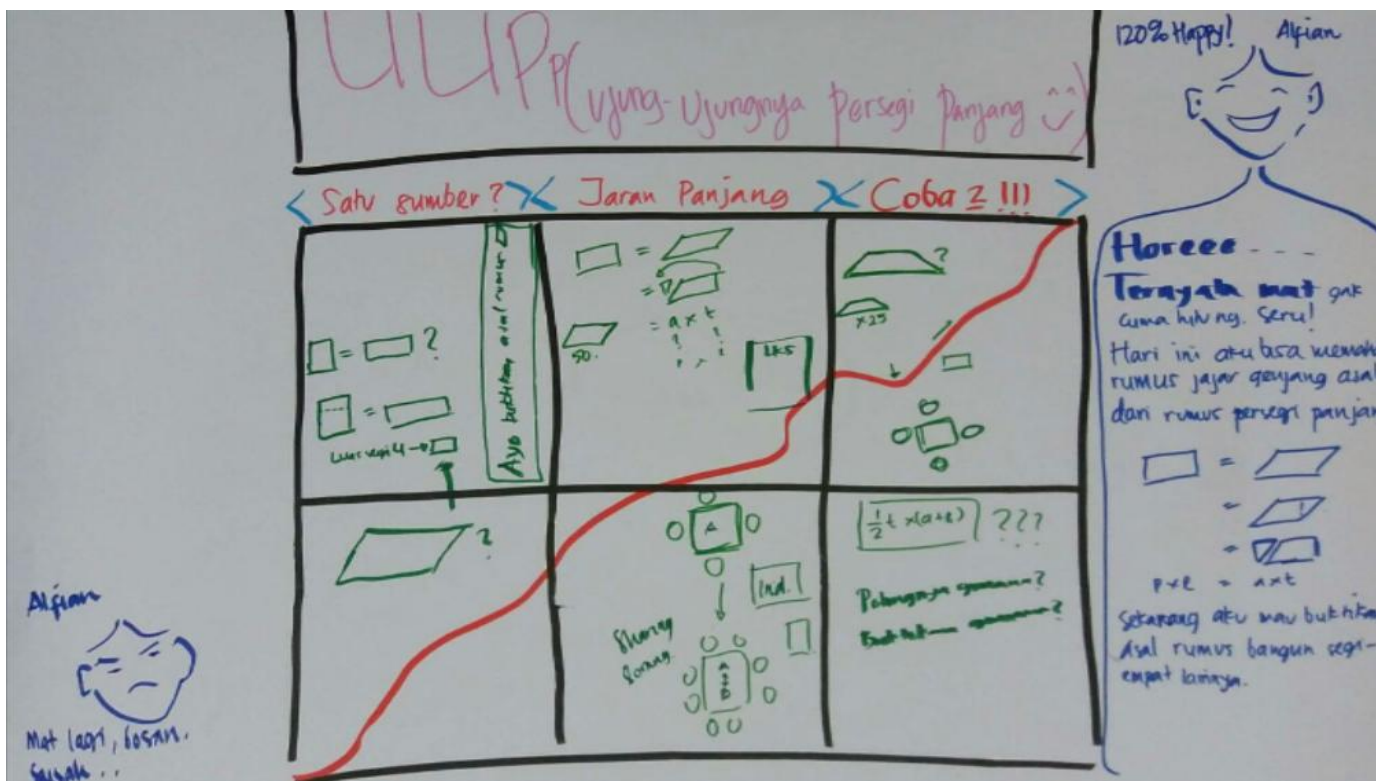

Gambar 2. Lesson Design plan 1

Kendala yang dihadapi saat kegiatan pelaksanaan pembelajaran $d o$ 1 :

1. Guru model kurang mampu memancing pertanyaan ke siswa.

2. Guru model kurang mampu memberi rangsangan ke siswa dapat mengkontruksi konsep.

3. Guru model kurang mampu mengelola waktu.

Temuan oleh observer (dari pengamatan langsung) saat kegiatan pelaksanaan pembelajaran do 1 :

1. Secara keseluruhan, siswa yang kesehariannya dalam kegiatan pembelajaran kurang aktif menjadi aktif selama kegiatan $d o$ see 1 berlangsung.

2. Selama kegiatan siswa merasa senang dan belajar dengan kondisi tidak tertekan.

3. Kerjasama siswa cukup bagus pada saat penemuan konsep luas jajargenjang dan lebih bagus lagi pada saat penemuan konsep trapesium.

4. Dalam satu kelompok, ada siswa yang awalnya kurang aktif menjadi aktif beraktifitas dengan dorongan teman di kelompoknya.
5. Sebagian besar siswa merasa tertantang dalam kegiatan ini.

6. Ada siswa yang bermain sendiri saat kegiatan.

7. Siswa belajar menemukan rumus dengan mengkonstruksi sendiri konsep luas tanpa menghafalkan rumus luas.

8. Para siswa menemukan 3 model guntingan berbeda luas jajargenjang menjadi luas persegi panjang.

9. Proses berpikir sebagian besar siswa sudah mengarah ke penemuan konsep luas.

10. Sebagian besar siswa sudah mampu berkomunikasi dan mempresentasikan hasil temuan.

11. Sebagian besar siswa mampu menemukan konsep luas jajargenjang.

12. Sebagian besar siswa tidak menemukan konsep trapesium karena waktu yang terbatas.

13. Daud dan Zidan tergolong siswa yang pendiam tetapi mereka mampu mengkonstruksi luas jajargenjang.

14. Alfian sebagai siswa sasaran lebih tertarik dalam pembelajaran 
Kegiatan tindak lanjut pada kegiatan evaluasi see 1:

1. Bagi siswa yang bermain sendiri saat kegiatan, solusinya adalah setiap siswa harus memegang alat peraga/media sendiri sehingga dapat meningkatkan keaktifan siswa.

2. Sebelum pembelajaran, guru model semampunya memikirkan semua kemungkinan yang dapat terjadi saat kegiatan pembelajaran.

3. Pembentukan kelompok sebaiknya memperhatikan faktor kemampuan, gender dan keaktifan sehingga diperoleh kelompok yang anggotanya heterogen.

\section{Kegiatan Plan-Do-See 2}

Materi yang dipilih pada kegiatan ini yaitu materi bangun ruang sisi datar tentang menemukan luas permukaan prisma. Ketercapaian kegiatan pelaksanaan pembelajaran adalah $70 \%$ dari kegiatan perencanaan. Pada kegiatan perencanaan (plan), sebanyak 15 guru secara bersama-sama membuat chapter design dan lesson design yang ditampilkan pada gambar berikut:

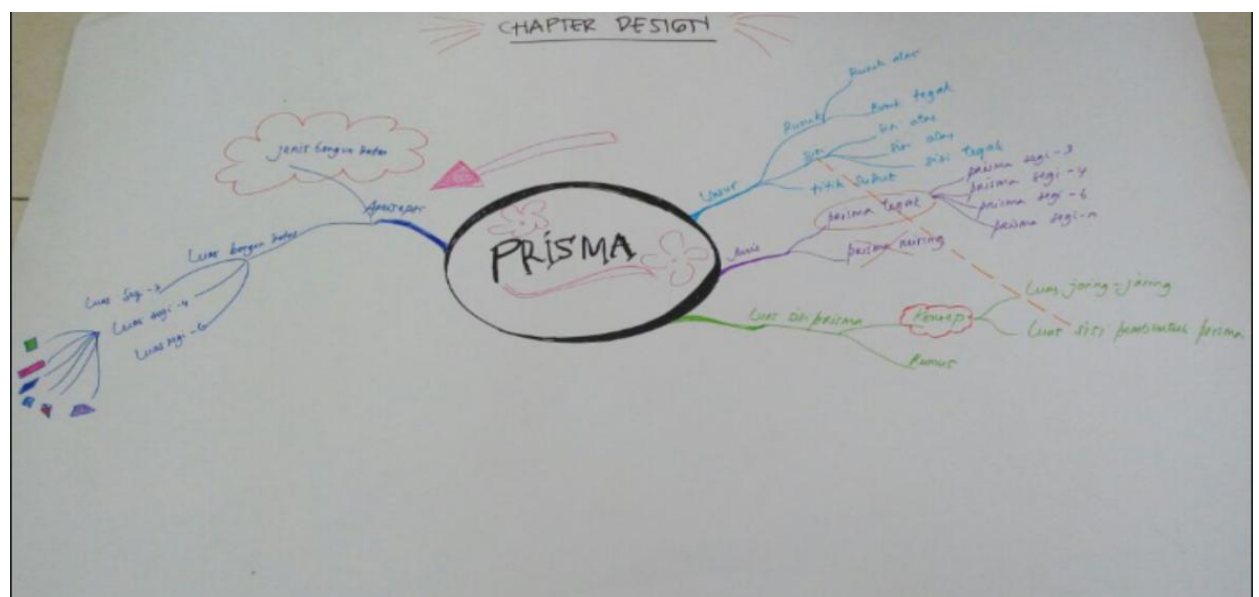

Gambar 3. Chapter Design plan 2

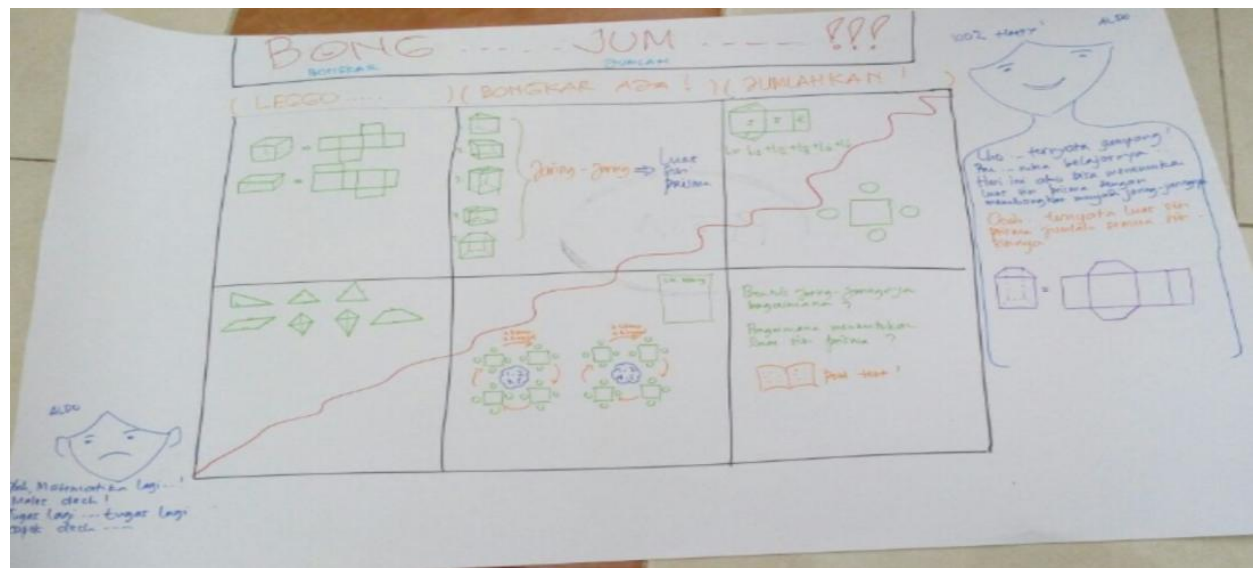

Gambar 4. Lesson Design plan 2 
Kendala yang dihadapi saat kegiatan pelaksanaan pembelajaran $d o$ 2:

1. Guru model kurang mampu memancing pertanyaan ke siswa.

2. Guru model kurang mampu memberi rangsangan ke siswa dapat mengkontruksi konsep.

3. Guru model kurang mampu menjadi fasilitator

Temuan oleh observer (dari pengamatan langsung) saat kegiatan pelaksanaan pembelajaran do 2 :

1. Guru model tidak melakukan kegiatan apersepsi di awal pembelajaran sehingga siswa merasa kebingungan dalam kegiatan do-see II.

2. Pembentukan kelompok berdasarkan no presensi kelas sehingga kurang heterogen.

3. Selama kegiatan siswa belajar dengan kondisi tertekan sehingga kelas menjadi sepi.

4. Diskusi kelompok kurang berjalan dengan baik.

5. Ada bangun ruang selain prisma yang ditemukan yaitu limas.

6. Siswa kurang berani mengkomunikasikan pendapat dan hasil temuannya.

7. Penemuan siswa kurang sesuai dengan rencana guru model yang telah disusun sebelumnya.

8. Dalam satu kelompok, ada siswa yang awalnya kurang aktif menjadi aktif beraktifitas dengan dorongan teman di kelompoknya.

9. Sebagian besar siswa merasa tertantang dalam kegiatan ini.

10. Ada siswa yang bermain sendiri saat kegiatan.
11. Siswa belajar menemukan rumus dengan mengkonstruksi sendiri konsep luas permukaan tanpa menghafalkan rumus luas.

12. Proses berpikir sebagian besar siswa sudah mengarah ke penemuan konsep luas.

Kegiatan tindak lanjut pada kegiatan evaluasi see 2:

1. Bagi siswa yang bermain sendiri saat kegiatan, solusinya adalah setiap siswa harus memegang alat peraga/media sendiri sehingga dapat meningkatkan keaktifan siswa.

2. Sebelum pembelajaran, guru model semampunya memikirkan semua kemungkinan yang dapat terjadi saat KBM.

3. Pembentukan kelompok sesebaiknya memperhatikan faktor kemampuan, gender dan keaktifan sehingga diperoleh kelompok yang anggotanya heterogen.

4. Guru di awal KBM harus menyampaikan apersepsi, tujuan pembelajaran dan proses kerja yang jelas ke siswa.

\section{Kegiatan Plan-Do-See 3}

Materi yang dipilih pada kegiatan ini yaitu materi segitiga tentang syarat membentuk segitiga dan jenis-jenis segitiga. Ketercapaian kegiatan pelaksanaan pembelajaran adalah $75 \%$ dari kegiatan perencanaan. Pada kegiatan perencanaan (plan), sebanyak 15 guru secara bersama-sama membuat chapter design dan lesson design yang ditampilkan pada gambar berikut: 


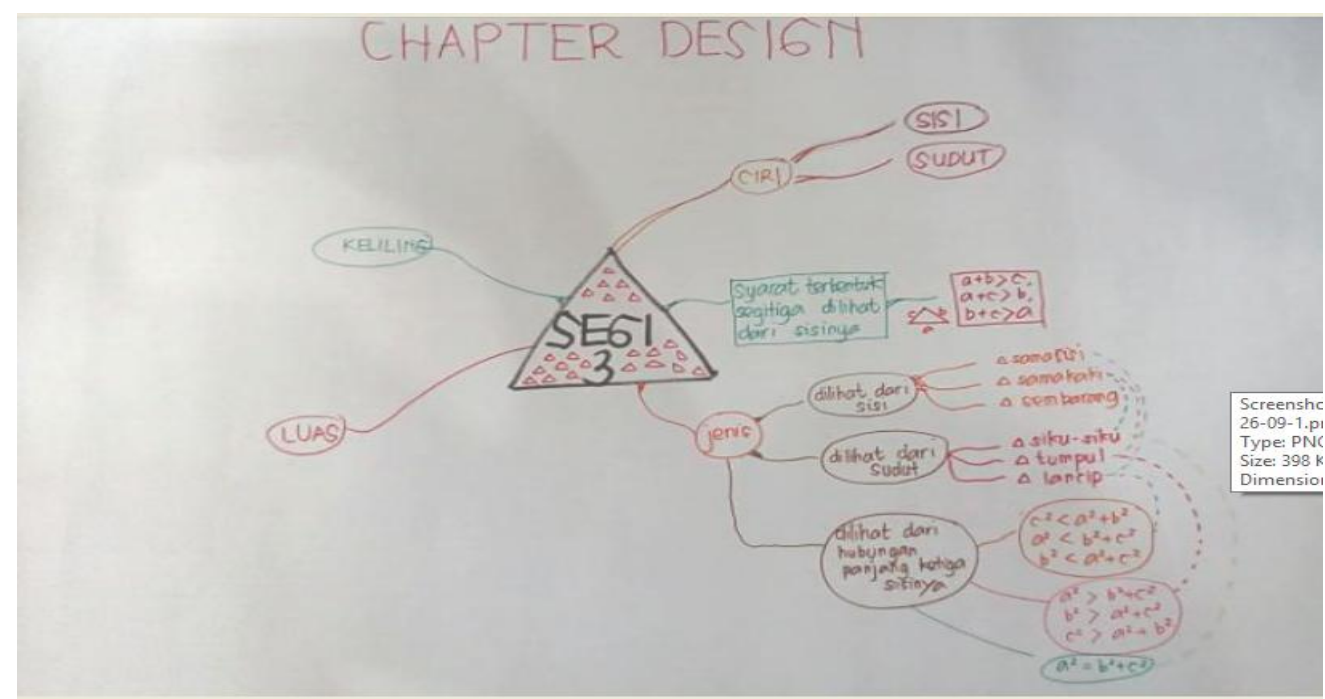

Gambar 5. Chapter Design plan 3

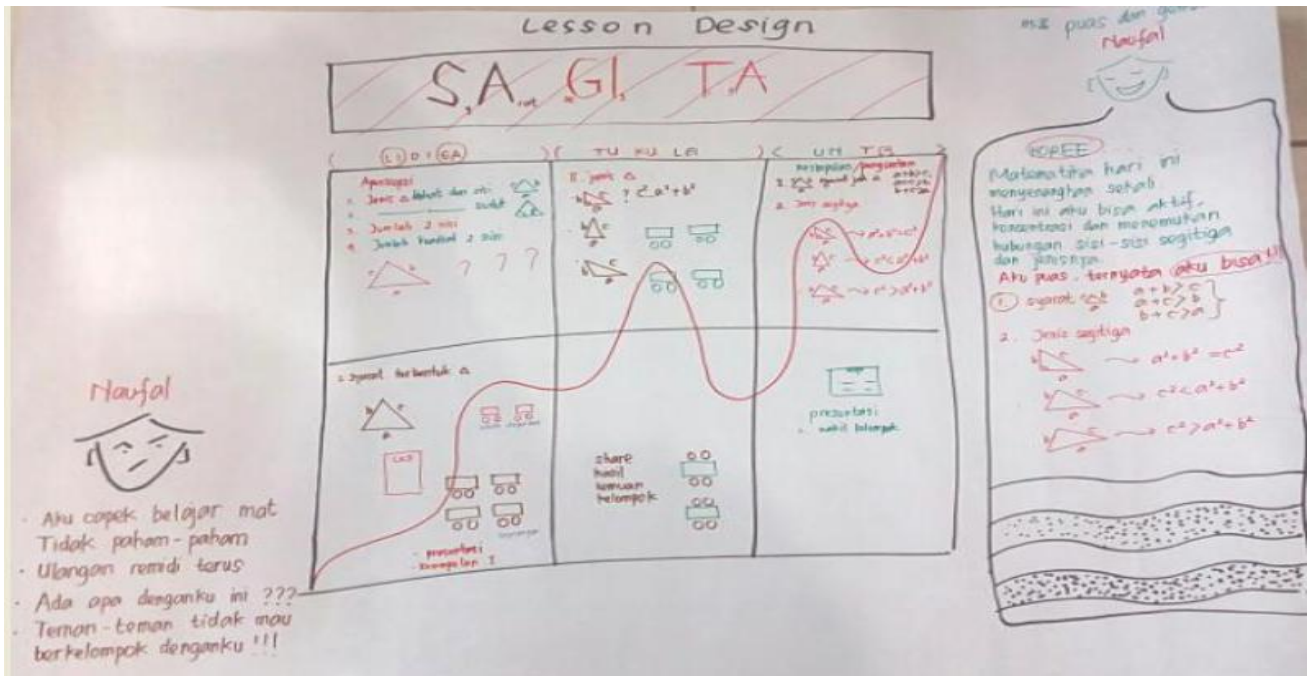

Gambar 6. Lesson Design plan 3

Kendala yang dihadapi saat kegiatan pelaksanaan pembelajaran do 3 :

1. Kesimpulan kegiatan 2 tidak berhasil karena siswa masih kesulitan menyimpulkan hubungan antara hubungan kuadrat panjang sisi-sisi segitiga.
2. Sesi kedua tidak dapat berjalan baik, siswa kebingunan membaca petunjuk langkah kerja pada LK

3. Terdapat keraguan pada siswa terhadap susunan lidi berikut apakah membentuk segitiga, 

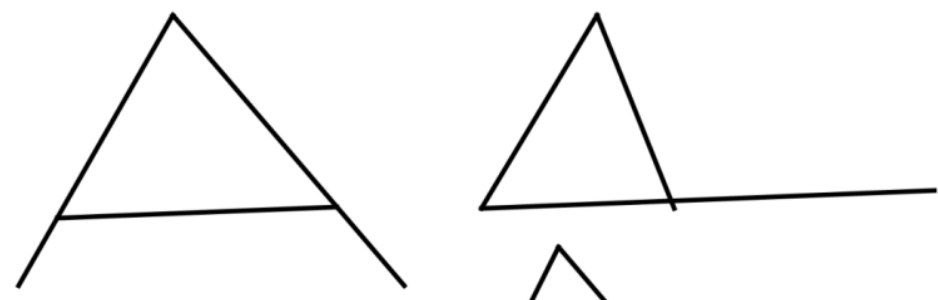

4. Terdapat siswa yang kesulitan mengukur sudut pada susunan lidi yang berbentuk segitiga menggunakan busur derajat, namun ternyata siswa mengaitkan dengan konsep jumlah sudut pada segitiga $180^{\circ}$.

5. Terdapat ketidak telitian siswa dalam menyusun lidi yang membentuk segitiga siku-siku yaitu ukuran $8,12,14$

Temuan oleh observer (dari pengamatan langsung) saat kegiatan pelaksanaan pembelajaran $d o 3$ :

1. Kelas yang dipakai merupakan siswa yang suka bicara namun ternyata dapat dikelola sedemikian sehingga rencana kegiatan pembelajaran yang disusun terlaksana dengan baik.

2. Semua siswa terlibat pada saat diskusi kelompok serta terdapat sharing yang aktif pada saat penyampaian ide

3. Siswa aktif mengerjakan Lembar Kegiatan (LK), jika ada kesulitan dalam pengerjaan LK siswa tidak segan bertanya kepada guru.

4. Berdasarkan hasil tahapan kegiatan 1 deskripsi siswa mengenai syarat terbentuknya segitiga meski tidak mirip namun setipe dengan " jumlah dua sisi lain lebih dari sisi terpanjang ".

5. Siswa yang menjadi target yaitu Naufal aktif dan senang selama pembelajaran berlangsung dan mampu menemukan konsep dengan memunculkan pernyataan "Oh ngono ta ...

6. Beberapa kalimat yang muncul pada saat pembelajaran diantaranya, " jika panjang suatu garis pada segitiga tidak pas maka tidak bisa jadi segitiga", "sisinya gak pas".

7. Terdapat diskusi yang cukup menarik yaitu bentuk yang tersusun dari 3 lidi sebagai berikut, apakah ini merupakan segitiga ?

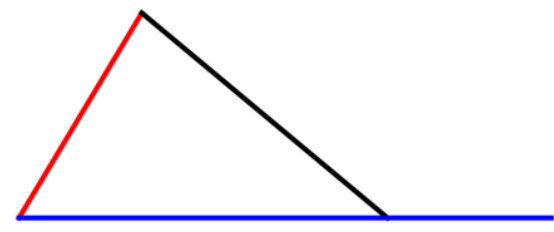

8. Antara anggota kelompok berkomunikasi saat menyusun kesimpulan.

9. Salah satu siswa aktif menyimpulkan dengan pernyataan
" seng gak iso dadi nek ukuran e gak podo".

10. Ukuran lidi yang dapat menjadi segitiga yang ditemukan oleh siswa mengarah ke segitiga sama sisi dan segitiga sama kaki. 
11. Siswa berani maju mempresentasikan hasil diskusi kelompoknya serta guru model menjadi fasilitator yang baik, guru bersikap terbuka mengikuti bahasa anak dan memotivasi siswa dengan memberi pernyataan diantaranya " ada, jangan menyerah, coba cari ", "kegiatan kedua lebih berat, semangat".

12. Pada saat kegiatan 2 mulai nampak pembagian tugas pada kelompok diskusi dpat dilihat dengan adanya siswa yang menulis ukuran lidi yang membentuk segitiga, ada yang mengukur sudutnya untuk menentukan segitiga yang terbentuk lancip, tumpul atau siku-siku.

13. Pada kegiatan kedua ada siswa yang mengingat kaitan antara teorema pythagoras dengan ukuran lidi yang dapt menyusun segitiga siku-siku, nampak melalui kalimat " $\mathrm{a}^{2}$ ditambah $\mathrm{b}^{2}$ hasil-e $c^{2}$ ngomongo ngomongo ".

14. Ketika akan menulis kesimpulan, beberapa pernyataan yang muncul diantaranya " mengukur panjang dulu, jenis sudutnya lancip tumpul atau sembarang ", " panjang sisi berbeda pasti jadi segitiga" kemudian disangkal dengan pernyataan " gak mesti ", “" pokoknya bisa menunjukkan sisinya bedanya jauh maka gak jadi segitiga", " ukuran tidak harus sama panjang dan tidak berbeda jauh".

Kegiatan tindak lanjut pada kegiatan evaluasi see 3:

1. Siswa tidak disarankan mengikuti bahasa guru, sebagai pendidik kita harus menerima bahwa jika kalimat siswa tidak sama dengan guru yang penting pemahaman siswa sama dengan tujuan pembelajaran.

2. Memfasilitasi bagaimana menampilkan contoh-contoh segitiga yang tidak istimewa yaitu segitiga sama sisi dan segitiga sama kaki.

3. Ada siswa yang tidak memperhatikan saat teman presentasi namun ketika diminta mengomentari jawaban teman dia ternyata menanggapi berarti siswa tersebut konsentrasi meski terlihat tidak peduli.

4. Apersepsi untuk menentukan jenis segitiga dari sudut dan panjang sisi diantaranya bilangan kuadrat.

5. Untuk menentukan tabel hubungan antara kuadrat panjang sisi perlu disepakati variabel untuk mewakilinya.

\section{PENUTUP}

Kami bersyukur memiliki temanteman yang memiliki komitmen cukup tinggi dalam berpartisipasi dalam kegiatan Lesson Study For Learning Comunnity ini. Tingkat partisipasi peserta selama kegiatan ini mencapai 96,7\%. Tidak tercapainya $100 \%$ karena ada beberapa tugas dan kegiatan yang bersamaan saat dilaksanakan kegiatan.

Banyak pengalaman berharga yang didapatkan dari kegiatan ini. Kami merangkum dari pendapat peserta yang disampaikan saat refleksi antara lain.

1. Mendapat pengalaman baru dengan mengenal dan dapat belajar membuat chapter design dan lesson design.

2. Berkolaborasi dalam menuangkan ide menyusun rencana pembelajaran.

3. Belajar menjadi observer yang baik, dalam dan tajam. Karena kedalaman dan ketajaman observer dalam melakukan observasi dapat menentukan kualitas diskusi saat refleksi.

4. Mengamati siswa yang belajar dan tidak belajar lengkap dengan prosesnya

5. Bagaimana guru mengajak siswa untuk berpikir yaitu dengan menciptakan tantangan atau 
kesulitan. Dengan demikian siswa akan berpikir dan memunculkan kreatifitas serta berinteraksi dengan siswa lain.

6. Sharing pengalaman dengan teman sejawat yang selama ini jarang bahkan belum pernah dilakukan

7. Menemukan fakta betapa banyak variasi cara dan sudut pandang berpikir siswa sesuai dengan pengalaman dan kemampuan yang dimiliki: Siswa yang dianggap kurang mampu ternyata dapat mengikuti pelajaran dengan baik jika plan yang dibuat sesuai dengan kebutuhan dan gaya belajar siswa kekurangan dalam melaksanakan pembelajaran:

8. Mengingatkan bahwa kita sebagai guru bahwa masih banyak

9. Menemukan masalah yang hampir sama pada saat pembelajaran: siswa kurang konsentrasi, berbicara sendiri, kurang aktif dalam mengikuti pembelajaran dll

10. Keberhasilan lesson study tidak hanya bergantung pada baik tidaknya plan dan guru model dalam membelajarkan tetapi juga pada kualitas hasil observasi, refleksi dan tindak lanjutnya.

Untuk rencana tindak lanjut, kegiatan yang sangat baik ini akan diprogramkan untuk dideseminasikan dan dikembangkan di lingkungan MGMP dengan bimbingan dan pendampingan Tim Lesson Study Kota Malang, meskipun hal ini tidak mudah karena tugas dan jadwal guru yang padat di sekolah serta adanya program SIMPKB yang ditugaskan kepada MGMP Matematika oleh Kemendikbud melalui P4TK Matematika. Diperlukan dukungan dan komitmen dari berbagai pihak: Kepala Sekolah, Dinas Pendidikan, Tim Lesson Study Kota Malang agar pendeseminasian dan pengembangan Lesson Study Berbasis Komunitas ini untuk memperbaiki pembelajaran ini bisa berjalan dengan baik. Tetapi unsur yang terpenting dalam hal ini adalah minat dan komitmen guru itu sendiri dan pengurus MGMP dalam memprogramkan dan memfasilitasi anggota dalam melaksanakan lesson study.

\section{DAFTAR RUJUKAN}

Baba, Takuya. 2007. How is Lesson Study Implemented? Dalam Isoda, M. Stephen, $M . \quad$ Ohara $Y, \&$ Miyakawa, T. Japanese Lesson Study in Mathematics Its Impact, Diversity and Potential for Educational Improvement. New Jersey USA: World Scientific Publishing Co. Pte. Ltd.

Depdiknas. 2009. Program Perluasan Lesson Study Untuk Penguatan LPTK. Jakarta.

Friedkin, Shelley. 2005. What is Lesson Study?, (Online), (http: //www.lessonresearch.net), diakses: 11 September 2005.

Sparks, Dannis. 1999. Overview of Lesson Study, (Online), (http://www.nwrel.org/msec/lesson study/overview.html), diakses: 27 Juni 2006.

Sukirman. 2006. Peningkatan Profesionalisme Guru Melalui Lesson Study. Makalah disampaikan pada kegiatan Pelatihan 2 hari untuk fasilitator dan Tim TPK SISTTEMS Bantul Emergency Program, Bantul, 11-12 Agustus 2006

Widjajanti, D. B. 2006. Pengembangan Kompetensi Guru Matematika Melalui Lesson Study. Makalah disampaikan pada Seminar Nasional dan Konferensi Nasional Matematika, Universitas Negeri Semarang, Semarang, 24-27 Juli 2006. 